Article

\title{
Worldwide Research Analysis on Natural Zeolites as Environmental Remediation Materials
}

\author{
Fernando Morante-Carballo ${ }^{1,2,3, * \mathbb{D}}$, Néstor Montalván-Burbano ${ }^{1,4} \mathbb{( D}$, Paúl Carrión-Mero ${ }^{1,5}$ (D) \\ and Kelly Jácome-Francis $1,5, *$
}

1 Centro de Investigación y Proyectos Aplicados a las Ciencias de la Tierra (CIPAT), ESPOL Polytechnic University, Guayaquil 09-01-5863, Ecuador; nmontalv@espol.edu.ec or nmb218@inlumine.ual.es (N.M.-B.); pcarrion@espol.edu.ec (P.C.-M.)

2 Facultad de Ciencias Naturales y Matemáticas (FCNM), ESPOL Polytechnic University, Guayaquil 09-01-5863, Ecuador

3 Geo-Recursos y Aplicaciones GIGA, ESPOL Polytechnic University, Guayaquil 09-01-5863, Ecuador

4 Department of Business and Economics, University of Almería, 04120 Almería, Spain

5 Facultad de Ingeniería en Ciencias de la Tierra (FICT), ESPOL Polytechnic University, Guayaquil 09-01-5863, Ecuador

* Correspondence: fmorante@espol.edu.ec (F.M.-C.); kjjacome@espol.edu.ec (K.J.-F.); Tel.: +593-96-385-5119 (F.M.-C.); +593-99-508-6800 (K.J.-F.)

check for updates

Citation: Morante-Carballo, F.; Montalván-Burbano, N.;

Carrión-Mero, P.; Jácome-Francis, K. Worldwide Research Analysis on Natural Zeolites as Environmental Remediation Materials. Sustainability 2021, 13, 6378. https://doi.org/ $10.3390 /$ su13116378

Academic Editor:

Anandram Venkatasubramanian

Received: 28 April 2021

Accepted: 30 May 2021

Published: 4 June 2021

Publisher's Note: MDPI stays neutral with regard to jurisdictional claims in published maps and institutional affiliations.

Copyright: (c) 2021 by the authors. Licensee MDPI, Basel, Switzerland. This article is an open access article distributed under the terms and conditions of the Creative Commons Attribution (CC BY) license (https:/ / creativecommons.org/licenses/by/ $4.0 /)$.
Abstract: Society faces a significant problem in regards to the spread of harmful products in the environment, primarily caused by accelerated growth and resource consumption. Consequently, there is a need for materials to be processed in less harmful ways and to remedy the contaminated sources they generate. Microporous materials have been studied for a long time and are used in waste treatment alternatives. Natural zeolites, on which this study is based, are attractive to the scientific and technological communities, due to their numerous applications as decontaminants and adsorption properties. This study analyzes the intellectual structures of publications related to natural zeolites in environmental remediation, using bibliometric methods to determine their volumes and trends. The methodology comprises of an analysis based on 1582 articles, using VOSviewer software, with data from 1974 to 2020, via the Scopus database. Results reflect a notable increase in publications from the end of the 1990s; the greatest contribution in the area comes from Eurasian countries. The study considers that development in this line of research will continue to increase and serve as a great contribution to preserve the environment in coming years, with themes that focus on water treatment (e.g., drinking water, wastewater, greywater), removal of heavy metals, ammonium, ammonia, and construction.

Keywords: natural zeolites; adsorbent; environmental remediation; bibliometric analysis; knowledge mapping

\section{Introduction}

Soil and water pollution have increased in recent decades [1] due to human activities (i.e., demand and consumption to meet growing population needs). The discharge of harmful pollutants into the environment, such as mercury $(\mathrm{Hg})$, lead $(\mathrm{Pb})$, arsenic (As), and cobalt (Co), can (directly or indirectly) cause numerous diseases and disorders [2]. Prolonged exposure or bioaccumulation of these agents [3] threaten food sources, nature, and health [4]. Urban, industrial, and mining waste contaminate soil and water [5]; moreover, an estimated 2000 million cubic meters of water are contaminated daily [3].

In order to preserve our environment, researchers seek materials and methods that counteract adverse environmental effects. Natural zeolites were discovered more than 200 years ago [6], and are studied due to their peculiar characteristics; for example, more than 20,000 articles and 2000 patents have been published on these materials to date [7]. 
The discovery of abundant deposits of natural zeolites (NZ) worldwide has led to more studies being conducted on these minerals, to understand their applications and benefits.

Natural zeolites can be described as "crystalline aluminosilicates with a three-dimensional structure based on repeating units of silicon-oxygen $\left(\mathrm{SiO}_{4}\right)$ and aluminium-oxygen $\left(\mathrm{AlO}_{4}\right)$ tetrahedra" [8]. They are also attributed as "molecular sieves" [9-11] due to their ability to accept and reject molecules based on their size [12]. On the other hand, regarding their origins, the geological environments of formation can vary: alteration of volcanic materials in fresh, brackish, and marine waters; hydrologically closed or open systems; volcanic materials in alkaline soils, and sediments metamorphosed by hydrothermal alteration $[6,8,13]$.

Among the characteristics that make zeolites unique materials compared to other crystalline inorganic oxides are: their tetrahedral structure, which give them different properties on the external and internal crystalline surface (high area); the exposure of the metal-oxygen tetrahedra on the internal surface makes them accessible to modifications (cation exchange, replacement of $\mathrm{Si}$ and $\mathrm{Al}$, the addition of metal particles); the ability to form diverse zeolite compositions and structures [14]. The main characteristics of the natural zeolites described in [15] are:

- A high degree of hydration;

- A high degree of crystallinity;

- Low density and the large volume of free spaces (dehydrated);

- Shape selectivity;

- Ion exchange characteristics;

- Catalytic characteristics;

- Sorption of molecules and ions;

- Electric conductivity.

One topic of interest is heavy metal contamination in soil and water since it constitutes a significant risk to nature and society [16,17]. Despite this, methods, such as ion exchange, chemical precipitation, reverse osmosis, carbon adsorption, solvent extraction, and electrodialysis [18-20], allow the removal of heavy metals, of which ion exchange is characterized by its simplicity of application [21]. However, the use of specific treatment methods may require high investment costs. Therefore, there is an increase in the search for alternative, low-cost materials (such as natural zeolites) to remove or stabilize heavy metals [8,22-24].

The study of zeolites is vast, as previously described by the authors in [6,7]. Nevertheless, it is estimated that only " $10 \%$ of natural zeolites have destined for wastewater treatment, animal feed, horticulture, odor control and other diverse applications, being $90 \%$ for the construction industry" $[25,26]$. The studies mainly focus on water treatment, wastewater management, soil decontamination, and nuclear waste. Zeolite applications in environmental remediation are mainly due to its ion exchange properties [27], where, depending on the type of zeolite, its pore size, the shape of its internal channels, and the type of exchange cation - it can interact with cations from the environment, with which it can have high selectivity [28-31]. In a medium where there are many cations, these can enter the internal structure of the zeolite by cation exchange, saturating it in a short time, and reducing its effectiveness.

Hundreds of investigations have been devoted toward studying water purification methods [32] and wastewater treatment (urban, industrial, mining, and agricultural). Case studies carried out on these topics include the removal of $\mathrm{Pb}$ (II) in wastewater, determining the affinity of mordenite with the cation [33]; as well as studies on the use of heulanditeclinoptilolite membranes in desalination and degreasing of water [34]; implementation of sorption columns filled with zeolites for wastewater treatment [35]; research on the adsorption capacity of clinoptilolite to remove pesticides from waters [36]; and heavy metals from acid mine drainage (AMD) [37].

On the other hand, other studies have been carried out, e.g., applying NZ as antibacterial agents based on their ion-exchange properties [38]. Likewise, research was conducted in the field of organic compounds, reporting the potential of NZ to stabilize 
mixed pollutants in sediments, including hydrophobic organic contaminants (HOCs), such as polycyclic aromatic hydrocarbons (PAHs), polybrominated diphenyl ethers (PBDEs), and pyrethroids [39]; the adsorption of non-ionic organic contaminants (NOC), such as benzene, toluene, and phenol in wastewater [40], and even the use of NZ in the pharmaceutical industry [41].

Zeolites are also used in radioactive materials, reflecting a great interest in their applications [42,43]. One example is their use to reduce the consequences of nuclear accidents, such as Chernobyl [44]. Moreover, they have a higher selectivity to certain radionuclides, such as ${ }^{90} \mathrm{Sr},{ }^{137} \mathrm{Cs},{ }^{60} \mathrm{Co},{ }^{45} \mathrm{Ca},{ }^{51} \mathrm{Cr}$, which, compared to organoresins, are cheaper and more resistant to nuclear degradation [6]. Similarly, NZ applications for soil remediation and protection are described $[45,46]$.

Applying these microporous materials for the remediation of the environment is the basis of this study. Scientific knowledge has increased in this area throughout the years, but not via large-scale applications. It is necessary to understand the journals, countries, documents, associated topics, and representative experts that have contributed to the development of this area, which will serve as a guide to obtain new data and develop research. It is feasible to consider the scientific publications on natural zeolites applied to environmental remediation in order to find patterns of techniques and applications registered in the Scopus database, to determine the main trends in relationships. The aim was to analyze the publications related to natural zeolites as environmental remediation materials in the Scopus database using bibliometric methods, applying VOSviewer to determine their intellectual structures and trends.

\section{Materials and Methods}

In scientific research, literature reviews are relevant to researchers, allowing them to know a particular area of knowledge under eligible criteria, and to minimize potential errors and biases when collecting information [47]. Bibliometric analyses exhibit similar procedures, by presenting formal and rigorous structure that allow the information displayed to be of quality $[48,49]$.

A bibliometric analysis provides researchers with tools (bibliometric methods) that guide them in their quests to collect essential information in a particular scientific field or discipline. Moreover, structure and development are recognized through thorough and precise processes [50,51]. Information can be seen through bibliometric maps, highlighting the most influential words (documents, countries, sources, authors, organizations) on a subject to carry out the comprehensive analysis [52]. This bibliometric analysis was structured in four stages, as shown in Figure 1, by collecting data to construct the information base that allowed the comprehensive evaluation of the field under study. Next, we explain the procedure.

\subsection{Defining the Appropriate Search Terms}

Some terms referred to natural zeolites in the academic literature, such as natural zeolite, natural zeolitic, and natural zeolitic material [53-55]. The common query term "natural zeolit ${ }^{*}$ " was selected, which facilitated a search for information and included the words already mentioned.

\subsection{Initial Search Results}

Bibliometric studies require the use of a database that has comprehensive coverage, with consistent and accurate data, to obtain a reliable base that provides quality information [56]. The Scopus database was selected because: (i) it is considered one of the largest databases with comprehensive coverage of documents in most academic disciplines [57,58]; (ii) it provides more excellent (in-time) coverage compared to other databases [59]; (iii) it provides excellent coverage of journals related to earth sciences [60]; and (iv) it provides tools that allow data visualization and analysis [61]. 


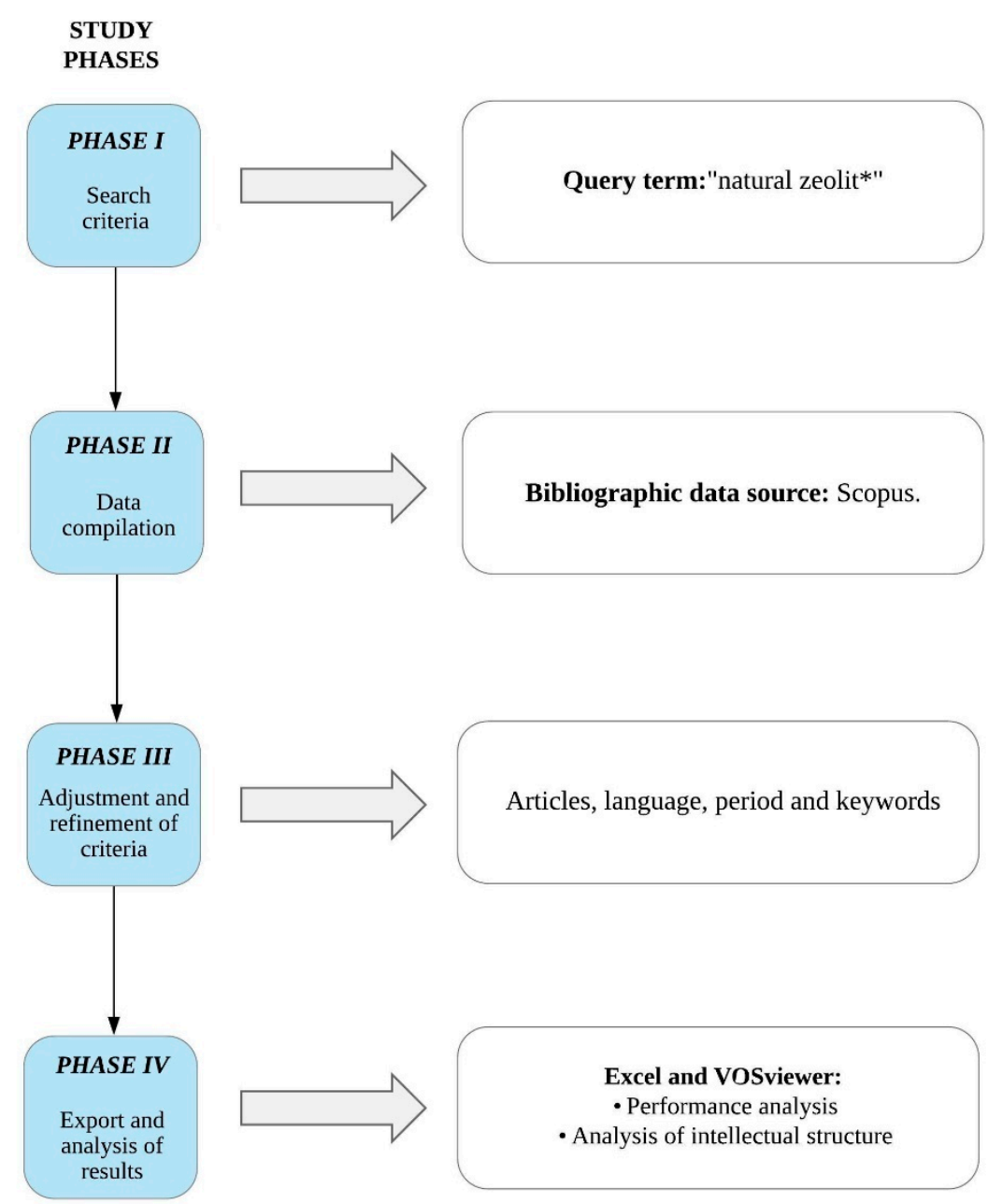

Figure 1. Methodological scheme for bibliometric analysis. The "** allows the word to be completed in both its singular and plural form.

The initial search of the data in this database was carried out in early August 2020. The search fields "article title, abstract and keyword" were applied, resulting in 3788 documents.

\subsection{Refinement of Search Results}

The initial data refinement was carried out using the information inclusion and exclusion criteria, by applying the type of document (article), language (English), and dates until 2020. The following search equation was utilized: TITLE-ABS-KEY ("natural zeolit") AND (LIMIT-TO (DOCTYPE, “ar")) AND (LIMIT-TO (LANGUAGE, “English”)).

Additionally, by seeking a more rigorous refinement that allowed obtaining a set of data that located natural zeolites as environmental remediation materials, the research was limited itself with exact words, grouped below for the ease of the reader: (Group A), Heavy Metal* , Metals, Metal ions, Ammonia, Ammonium, Soil Pollution, Water Pollution, Water Pollutant*, Wastewater, Waste Water, Industrial Waste; (Group B), Gas Adsorption, Pollutant Removal, Removal, Purification, Water Purification, Water Management, Water Treatment, Wastewater Treatment, Waster Water Management, Waste Component Removal, Waste Treatment and (Group C), Controlled Study, Experiment Study, and Groundwater. The selection of these words was made based on the high selectivity of NZ towards heavy metals and ammonium $[8,29,31]$, used mainly in the treatment, stabilization, and removal of said elements in drinking water, wastewater, and soil contamination. As a result of this initial refinement, a total of 1585 articles were obtained. 


\subsection{Data Extraction and Analysis}

Search results (1585) were downloaded in CSV (comma-separated values) format, and included the information in the following fields: citation information, bibliographic information, abstract, and keywords, and as additional information—references. For data analysis, two types of software were used:

(i) Microsoft Excel—in which the data were normalized to eliminate possible errors [62], a process in which three duplicate articles were found, and a total of 1582 articles were obtained. Additionally, the software allows analyzing scientific production in this field of study [63].

(ii) VOSviewer-a tool that allows the construction, exploration, and visualization of two-dimensional bibliometric networks, exposing a specific field's intellectual structure [52]. Moreover, it is handy since it allows the visualization of bibliometric maps in great detail through graphical representations of straightforward interpretations $[64,65]$. Science maps allow observing relationships between various variables that allow information on this structure obtained at a micro-level (co-occurrence of author keywords), meso-level (co-citation of cited authors), and macro level (co-citation of cited journals) $[66,67]$. VOSviewer is a friendly platform used to carry out these analyses; its creators provided documentation (manual and research articles) that allowed us to understand its functionality and use $[52,64,68]$. This program is used to study various scientific disciplines related to geology, for example, geotourism [69], fracking [70], and geological risks [71], as well as other areas of knowledge management [72], occupational health [73], education [74], etc.

\section{Results}

\subsection{Performance Analysis}

\subsubsection{Scientific Production Analysis}

Figure 2 presents a graph of scientific production, featuring the evolution of publications concerning the application of natural zeolites as environmental remedial materials, from 1973 to 2020, totaling 44,891 citations belonging to 1582 publications. One can observe more significant development in this area from the year 1997.

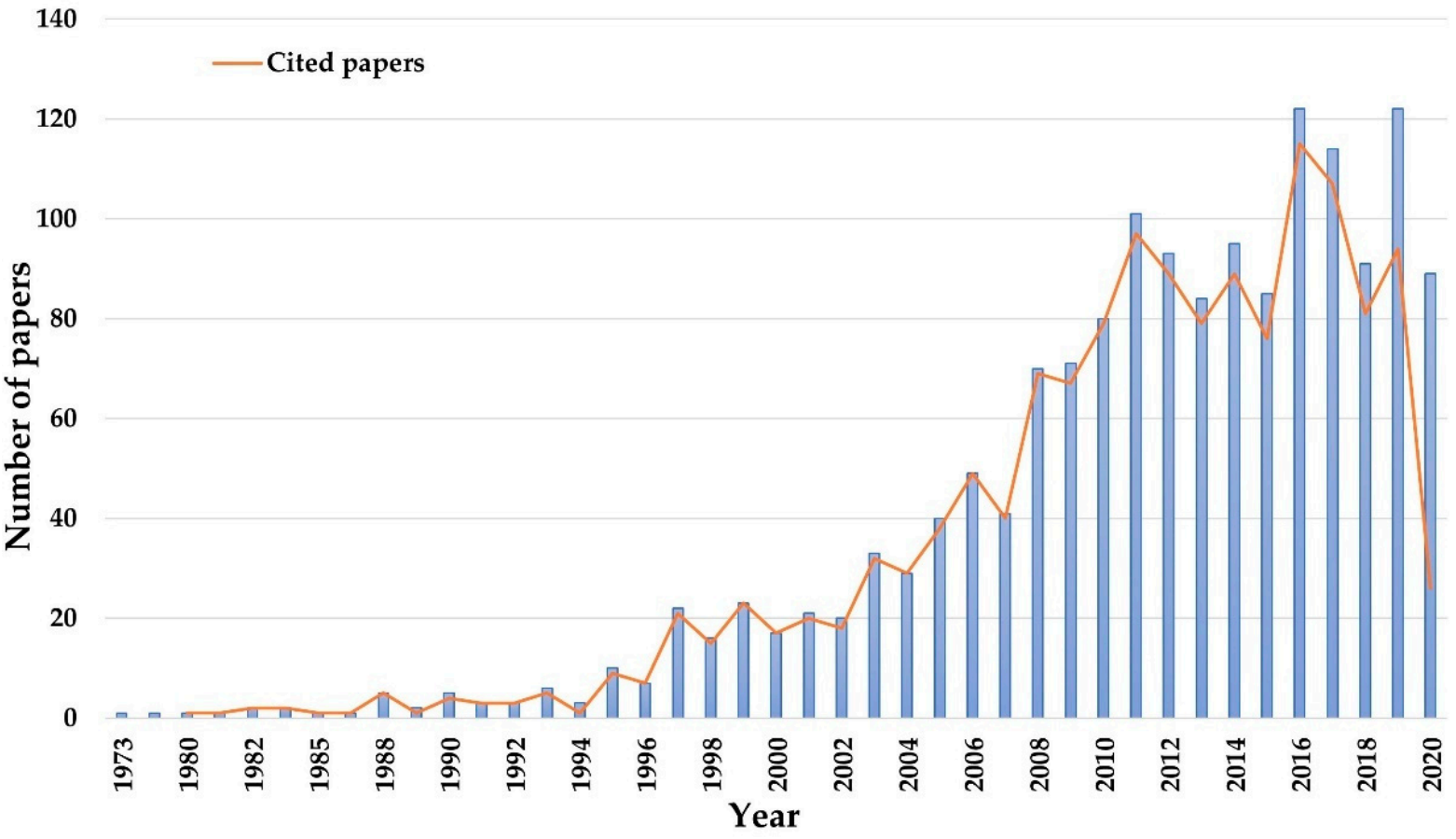

Figure 2. The growth trajectory of the literature on natural zeolites as environmental remedies, 1973-2020 (n = 1582). 
Publications on natural zeolites as environmental remedies began in the 1970s, representing $0.12 \%$ of papers; only two articles added eight citations, related to radioactive cobalt sorption [75] and the treatment of wastewater using clinoptilolite [76]. In the 1980s, there was a slight increase (15 publications). For example, [21] with 883 citations, and [77] with 108 citations - the authors dealt with the usefulness of NZ as ion exchangers for the removal of ammonium ions from drinking water, and conducted a study on the influence of pretreatment on the capacity and selectivity of clinoptilolite to metal ions, respectively. In the 1990s, a notable increase was observed, with a total of 98 publications $(6.15 \%)$, among them, Mumpton (1999) stands out, with the highest number of citations at the time (477); his article referred to the various uses of natural zeolites. Moreover, [78], with 285 citations, focused on removing lead and cadmium from wastewater. The most cited years were 1997 and 1999, accumulating 1378 and 1709 citations, respectively. Later, in the 2000s, there was a significant increase $(24.65 \%)$, with a total of 391 papers $(21,000 / 44,891$ citations). There were 2522 citations obtained from 2007, dealing with issues such as ammonium ion removal efficiency using a natural Turkish zeolite (for environmental quality) [79]; NZ as adsorbents to remove malachite green and $\mathrm{Pb}^{2+}$ ions from an aqueous solution [80]; and lead retention by a Mexican tuff rich in clinoptilolite [81]. Likewise, there were 2694 citations obtained from 2009, with topics focusing on heavy metal adsorption from mining acid drains [82]; the remediation of lead-contaminated soil using NZ [83], and the adsorption of uranium (VI) on manganese oxide-coated zeolite (MOCZ) of an aqueous solution [84].

Finally, from 2010, the most significant contributions in this area are presented, covering $68.14 \%$ of articles (1076 out of 1582 ) with a total of $17,805 / 44,891$ citations. The topics highlighted benefits of natural zeolites due to their adsorption properties [85], ion exchange [30], and porosity [86], which could be applied in different settings.

\subsubsection{Country Contribution}

Table 1 lists 10 out of 81 countries (using natural zeolites for environmental remediation) that have the highest number of publications and citations on environmental remediation. Major countries that top the list include Turkey, with a total of 195 publications and the highest number of citations (6940), followed by China, with 161 publications and 5618 citations, and Iran, with 155 publications and 3866 citations.

Table 1. Top 10 countries with the most publications in the area.

\begin{tabular}{cccc}
\hline Rank & Country & Documents & Citations Count \\
\hline 1 & Turkey & 195 & 6940 \\
2 & China & 161 & 5618 \\
3 & Iran & 155 & 3866 \\
4 & United States & 90 & 3970 \\
5 & Italy & 81 & 1733 \\
6 & Australia & 62 & 3056 \\
7 & Indonesia & 62 & 384 \\
8 & Mexico & 62 & 1621 \\
9 & Greece & 60 & 2162 \\
\end{tabular}

Table 1shows that most of these countries belong to Europe or Asia, followed by America and Oceania. However, variations of this list exist among the most cited countries (Table S1). Turkey and China top the list, but the United States ranks third, with 3970 citations (90 documents), Iran fourth, followed by Australia (3056 citations).

Greece moves up to sixth place, with 2162 citations, and Croatia (1758 citations) joins the top 10, followed by Spain (1751 citations), Italy (1733 citations), and Canada (1642 citations). A deeper analysis revealed that, among the countries published in the study area, the majority belong to the European continent, representing $40 \%$ of all countries, followed by the Asian continent, with $36 \%$. Surprisingly, only Eurasia represents $76 \%$ of 
publications, followed by America, which accounts for $14 \%$; the most significant contributions correspond mainly to Canada, the United States, and Mexico. Next, Africa makes up $9 \%$ of the countries, with Egypt (17 documents and 398 citations) and South Africa (13 documents and 166 citations) as the main contributors. Finally, Oceania represents $2 \%$; its contributions come from Australia (62 publications and 3056 citations) and New Zealand (nine publications and 478 citations).

\subsubsection{Journal's Performance}

Table 2 shows the top 10 journals published in this field of study, out of a set of 564 journals, where the number of articles (AT), contribution percentage (\%), H-Index (HI), SCImago Journal Rank (SJR), and the journal quartile was considered. The journals shown have a total of 349 publications, representing $22.06 \%$ of the 1582 articles obtained, receiving $19,187(42.74 \%)$ citations of the total citations $(44,891)$. The first three journals on the list are: Microporous and Mesoporous Materials, with 69 publications in total, corresponding to $4.36 \%$ of all articles collected, with $\mathrm{HI}$ of $151, \mathrm{SJR}=1$ and Q1. In second place is the Journal of Hazardous Materials (4.11\%, 63 publications, HI: 260, SJR: 1, Q1), and in third, Construction and Building Materials (2.40\%, 38 publications, HI: 147, SJR: 1.49, Q1).

Table 2. Top 10 journals with the highest number of publications.

\begin{tabular}{|c|c|c|c|c|c|c|}
\hline Rank & Journal & $\mathrm{AT}^{1}$ & $\%^{2}$ & $\mathrm{HI}^{3}$ & $\mathrm{SJR}^{4}$ & Quartile \\
\hline 1 & Microporous and Mesoporous Materials & 69 & 4.36 & 151 & 1 & Q1 \\
\hline 2 & Journal of Hazardous Materials & 65 & 4.11 & 260 & 2.01 & Q1 \\
\hline 3 & Construction and Building Materials & 38 & 2.40 & 147 & 1.49 & Q1 \\
\hline 4 & Desalination and Water Treatment & 32 & 2.02 & 51 & 0.33 & Q2 \\
\hline 5 & Chemical Engineering Journal & 27 & 1.71 & 198 & 2.32 & $\hat{\mathrm{Q} 1}$ \\
\hline 6 & Water Research & 26 & 1.64 & 285 & 2.93 & Q1 \\
\hline 7 & Water Science and Technology & 24 & 1.52 & 131 & 0.47 & Q2 \\
\hline 8 & Desalination & 24 & 1.52 & 169 & 1.81 & Q1 \\
\hline 9 & Bioresource Technology & 22 & 1.39 & 273 & 2.43 & Q1 \\
\hline 10 & $\begin{array}{l}\text { Journal of Environmental Science and Health-Part A } \\
\text { Toxic/Hazardous Substances and Environmental Engineering }\end{array}$ & 22 & 1.39 & 67 & 0.48 & Q2 \\
\hline
\end{tabular}

${ }^{1} \mathrm{AT}=$ articles $;{ }^{2} \%=$ contribution percentage $;{ }^{3} \mathrm{HI}=\mathrm{H}$-Index; ${ }^{4} \mathrm{SJR}=$ SCImago journal rank.

\subsubsection{Author Contribution}

Table 3 presents the rank $(\mathrm{R})$ of the 10 principal authors who contributed significantly to the use of NZ as valuable materials for environmental remediation. The number of publications, citations, and H-index in this area was analyzed to identify the top 10 out of 4436 authors.

Karapinar Nazan from Pamukkale Üniversitesi (Turkey) stands out for the number of citations accumulated, with 1172 citations in the area, which places him in first place on the list.

These citations belong to two publications; the first is a 2004 publication regarding the removal of heavy metal cations (1061 citations) in the Journal of Colloid and Interface Science [87]; and the second concerns phosphorus and ammonium removal from a 2009 publication, in the Journal of Hazardous Materials, with 111 citations. The first publication involved a collaboration with two authors from this list, Erdem Emin and Donat Ramazan, from the same institute, with 1061 citations each, but corresponding to the same publication.

In second place on the top 10 list is Wang Shaobin, from the University of Adelaide, Australia, with 1151 citations and the highest H-index (111). He has 12 publications on the subject, the most cited publication concerns removing basic dyes from aqueous solutions (279 citations).

The author with the highest number of publications on this list is Shekarchi Maryam, with 15 publications and 814 citations. Likewise, three authors on the list share the same publication that deals with removing heavy metals in water, with 883 citations each. 
Table 3. Top 10 authors in NZ studies related to environmental remediation.

\begin{tabular}{|c|c|c|c|c|c|c|}
\hline $\mathbf{R}^{1}$ & Authors & Country & Institute/University & Citations Count & Publications & $\mathrm{HI}^{2}$ \\
\hline 1 & Karapinar N. & Turkey & Pamukkale Üniversitesi & 1172 & 2 & 6 \\
\hline 2 & Wang S. & Australia & The University of Adelaide & 1151 & 12 & 111 \\
\hline 3 & Erdem E. & Turkey & Pamukkale Üniversitesi & 1061 & 1 & 11 \\
\hline 4 & Donat R. & Turkey & Pamukkale Üniversitesi & 1061 & 1 & 12 \\
\hline 5 & Maunaye M. & France & $\begin{array}{c}\text { ENSCR Ecole Nationale } \\
\text { Supérieure de Chimie de Rennes }\end{array}$ & 883 & 1 & 10 \\
\hline 6 & Martin G. & France & $\begin{array}{l}\text { ENSCR Ecole Nationale } \\
\text { Supérieure de Chimie de Rennes }\end{array}$ & 883 & 1 & 17 \\
\hline 7 & Blanchard G. & France & $\begin{array}{l}\text { ENSCR Ecole Nationale } \\
\text { Supérieure de Chimie de Rennes }\end{array}$ & 883 & 1 & 1 \\
\hline 8 & Shekarchi M. & Iran & $\begin{array}{l}\text { Iranian Ministry of Health and } \\
\text { Medical Education }\end{array}$ & 814 & 15 & 13 \\
\hline 9 & Lin J. & Taiwan & $\begin{array}{l}\text { National Chiao Tung } \\
\text { University Taiwan }\end{array}$ & 758 & 10 & 35 \\
\hline 10 & Trgo M. & Croatia & Sveučilište u Splitu & 703 & 13 & 10 \\
\hline
\end{tabular}

${ }^{1} \mathrm{R}=$ Rank; ${ }^{2} \mathrm{HI}=$ H-Index.

\subsubsection{Frequently Cited Documents}

Table 4 shows the 10 most cited articles on the subject, which, together, add up to a total of 5022/44,891 citations. Additionally, the number of citations received for published articles (TC) and the Annual Citation Index (ACI) are included.

Table 4. Top 10 most cited articles.

\begin{tabular}{|c|c|c|c|c|c|c|}
\hline Rank & Article Title & Authors & $\begin{array}{c}\text { Type of } \\
\text { Document }\end{array}$ & $\mathrm{TC}^{1}$ & Year & $\mathrm{ACI}^{2}$ \\
\hline 1 & $\begin{array}{l}\text { The removal of heavy metal cations by } \\
\text { natural zeolites }\end{array}$ & [87] & Article & 1061 & 2004 & 62.4 \\
\hline 2 & $\begin{array}{c}\text { Removal of heavy metals from waters by means of } \\
\text { natural zeolites }\end{array}$ & [21] & Article & 883 & 1984 & 23.9 \\
\hline 3 & $\begin{array}{c}\text { La roca magica: Uses of natural zeolites in } \\
\text { agriculture and industry }\end{array}$ & [6] & Review & 477 & 1999 & 21.7 \\
\hline 4 & $\begin{array}{l}\text { Adsorption of basic dyes on granular activated } \\
\text { carbon and natural zeolite }\end{array}$ & [88] & Article & 467 & 2001 & 23.4 \\
\hline 5 & $\begin{array}{c}\text { Arsenic-A review. Part II: Oxidation of arsenic and } \\
\text { its removal in water treatment }\end{array}$ & [89] & Review & 398 & 2003 & 22.1 \\
\hline 6 & $\begin{array}{l}\text { Removal of zinc, copper and lead by natural } \\
\text { zeolite-A comparison of adsorption isotherms }\end{array}$ & [90] & Article & 394 & 2004 & 23.2 \\
\hline 7 & $\begin{array}{c}\text { Purification of metal electroplating waste waters } \\
\text { using zeolites }\end{array}$ & [91] & Article & 370 & 2003 & 20.6 \\
\hline 8 & $\begin{array}{c}\text { Adsorption characteristics of natural zeolites as solid } \\
\text { adsorbents for phenol removal from aqueous } \\
\text { solutions: Kinetics, mechanism, and } \\
\text { thermodynamics studies }\end{array}$ & [85] & Article & 337 & 2011 & 33.7 \\
\hline 9 & $\begin{array}{c}\text { Study of equilibrium, kinetic and thermodynamic } \\
\text { parameters about methylene blue adsorption onto } \\
\text { natural zeolite }\end{array}$ & [92] & Article & 319 & 2009 & 26.6 \\
\hline 10 & $\begin{array}{l}\text { Adsorption of heavy metals from acid mine drainage } \\
\text { by natural zeolite }\end{array}$ & [82] & Article & 316 & 2009 & 26.3 \\
\hline
\end{tabular}

${ }^{1} \mathrm{TC}=$ the total number of citations received for published articles; ${ }^{2} \mathrm{ACI}=$ Annual Citation Index.

The three most cited documents are described below:

The first document was published in the Journal of Colloid and Interface Science; in this research, the authors propose using NZ as alternatives due to their low cost and availability. Furthermore, they emphasize the effectiveness of natural zeolites properties (clinoptilolite), specifically "adsorption", to eradicate metal cations, such as $\mathrm{Co}^{2+}, \mathrm{Cu}^{2+}, \mathrm{Zn}^{2+}$, and $\mathrm{Mn}^{2+}$ from wastewater. 
Second, published in the journal Water Research, and like the previous document, it uses clinoptilolite (in drinking water) with the "ion exchange" method, through the property of selectivity of the material to eliminate ammonium ions.

Occupying third place, and published in the journal Proceedings of the National Academy of Sciences of the United States of America, this article compiles the essential aspects of the properties of these microporous materials in various areas (agriculture, construction, medicine, water treatment, etc.), in which they promise significant contributions.

It is necessary to consider that, some of the most cited articles do not necessarily have a more significant number of citations per year. For this reason, the Annual Citation Index (ACI) was proposed, which establishes the relationship between the total number of citations and the age of the document. Table 4 shows this index; the document of 2004 [87] has the highest index, showing an average of 62.4 annual citations. Afterward, a more recent article (2011) [85] with an ACI $=33.7$, and a third, from the year 2009, with an ACI (26.6).

\subsection{Intellectual Structure Analysis}

\subsubsection{Author's Keyword Co-Occurrence Network}

Author keywords were used through a content analysis technique that allows the construction of semantic visual maps, showing the study area's cognitive structure and most relevant topics $[50,71,93]$. For this purpose, the VOSviewer software was used to construct the bibliometric co-occurrence map, using the mentioned words; 3323 keywords were recorded, obtained from 1582 publications. Only 638 words matched at least twice, 84 words at least five times, and 42 (ten times).

Keywords are presented in Figure 3, employing nodes, which vary in size according to the number of times the keyword appears in documents. Similarly, keywords are related to each other through links, where a higher degree of relationship is presented with a greater width of the link, showing a better relationship between the words. According to node colors, keywords are grouped into 11 groups, 84 words with 698 links, and a total strength of 2448 .

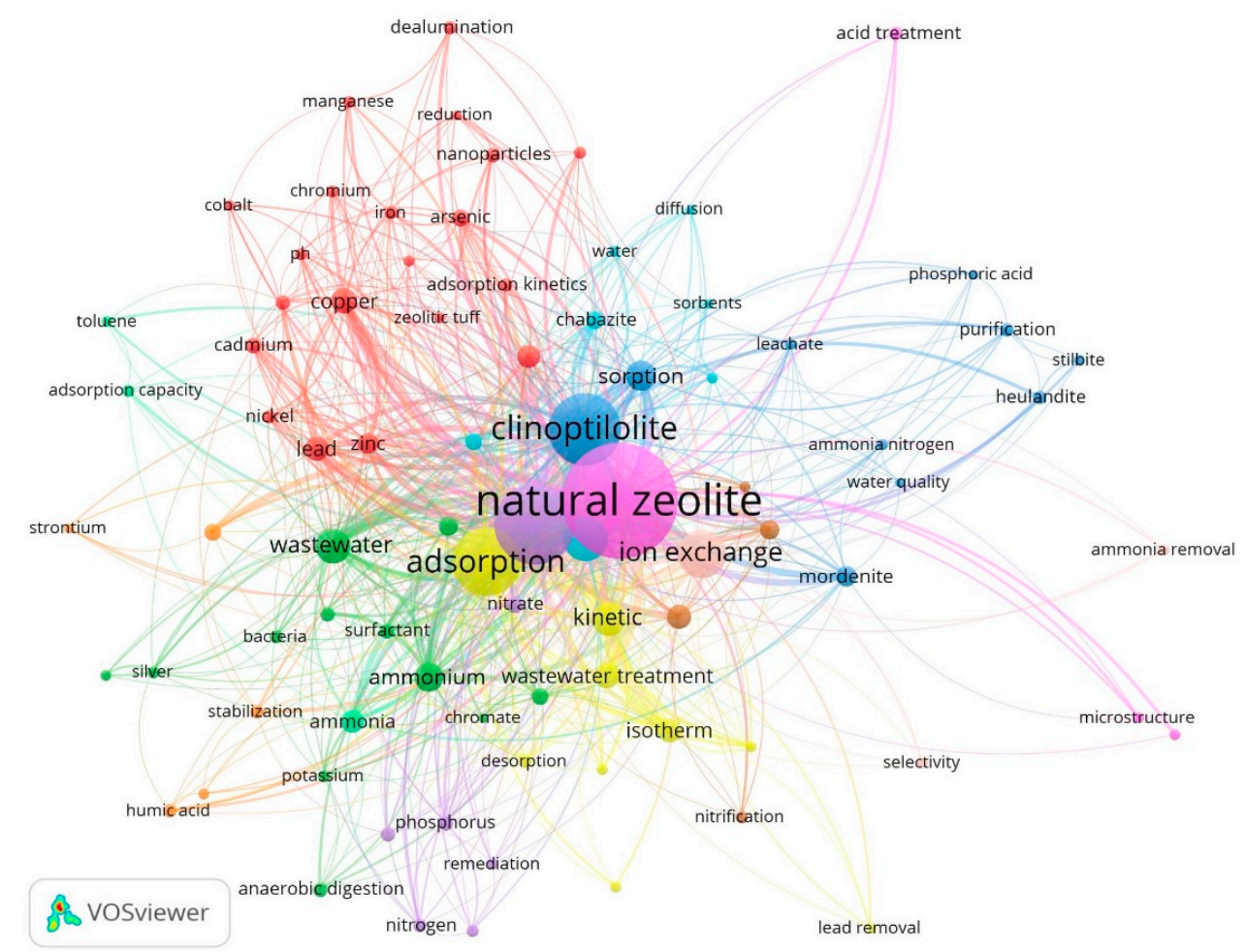

Figure 3. Co-occurrence bibliometric map of author keywords. 
The author keyword network analysis was based on the number of co-occurrences represented in the nodes (circles) of colors, starting from those with the most significant numbers to those with the least numbers. The description of each cluster was made based on the main nodes shown in Figure 3 and Table S2. In addition, the 20 most used keywords based on the number of co-occurrences are in Table 5. The period comprises the years 19732020, divided into four sub-periods that correspond to decades to facilitate the analysis. The Table 5 initially shows seven terms that comprise this structure's origin, consolidated into 20 main topics over the years. The topics (terms) are highlighted: natural zeolite (667 articles), zeolite (329), and clinoptilolite (259).

Table 5. Top 20 keywords (1973-2020).

\begin{tabular}{|c|c|c|c|c|c|}
\hline Keyword & Occurrences & 1973-1989 & 1990-1999 & 2000-2009 & $2010-2020$ \\
\hline natural zeolite & 667 & - & 39 & 159 & 469 \\
\hline zeolite & 329 & 1 & 11 & 84 & 233 \\
\hline clinoptilolite & 259 & 3 & 10 & 97 & 149 \\
\hline adsorption & 237 & - & 2 & 52 & 183 \\
\hline ion exchange & 119 & 3 & 9 & 53 & 54 \\
\hline heavy metal & 99 & - & 3 & 31 & 65 \\
\hline wastewater & 61 & 1 & 4 & 18 & 38 \\
\hline kinetic & 60 & - & - & 15 & 45 \\
\hline sorption & 48 & - & 2 & 15 & 31 \\
\hline ammonium & 43 & - & 2 & 10 & 31 \\
\hline copper & 34 & - & 1 & 14 & 19 \\
\hline wastewater treatment & 32 & - & 1 & 8 & 23 \\
\hline isotherm & 31 & - & - & 7 & 24 \\
\hline water treatment & 31 & - & 1 & 11 & 19 \\
\hline lead & 30 & - & 3 & 12 & 15 \\
\hline adsorption isotherm & 28 & - & 1 & 4 & 23 \\
\hline ammonia & 26 & 1 & 2 & 10 & 13 \\
\hline mordenite & 22 & 1 & 4 & 6 & 11 \\
\hline zinc & 22 & - & - & 11 & 11 \\
\hline ammonium removal & 20 & 1 & 2 & 4 & 13 \\
\hline
\end{tabular}

Cluster 9 (pink), called "Acid Water (AW) treatment with NZ" (see Table S1), is composed of four nodes with 690 co-occurrences, and studies the capacity of natural zeolites in the treatment of acidic waters [94], taking advantage of the adsorption properties [95], ion exchange [96] to facilitate the removal of heavy metals, and reduce pollution damage due to acid mine waters [97]. This cluster shows the main keywords, "natural zeolite", "acid treatment", and "microstructure". The first of the terms mentioned, "natural zeolite", is the nucleus of this structure, with 667 co-occurrences.

Cluster 4 (yellow), "Kinetic of adsorption", consists of nine nodes with 393 cooccurrences, where simulations [98] and various models [99] are applied in kinetic studies [100] to study the adsorption characteristics of NZ to various elements [85]. This cluster presents some keywords that stand out for their occurrence, such as "adsorption", "kinetic", and "isotherm".

Cluster 5 (purple), "NZ soil remediation" has seven nodes (392 co-occurrences), studies that test the effectiveness of mineral amendments with natural zeolites [101], to remediate soils with potentially toxic elements (PTE) [102] extracting or immobilizing metals [103], in order to limit environmental impacts and protect the quality of soils [104]. It has keywords like "zeolite", "remediation", and "nitrogen".

Cluster 3 (blue), "NZ water purification", is formed by 10 nodes with 379 co-occurrences. Various topics on water purification are dealt with, presenting methods such as desalination and de-oiling of water with natural zeolite membranes [34], treatments for nitrate removal [105], treatments are evaluated in waters contaminated with endocrine disruptors [106] and even the purification of groundwater [107], with keywords "purification", "water quality", and "clinoptilolite". 
Cluster 1 (red) called "Metal removal" with 20 nodes and 258 co-occurrences, with topics that study the equilibrium [108] and adsorption forces [109], the kinetics of removal [110] and affinity towards heavy metal ions [111], has keywords such as "copper", "lead", and "zinc".

Cluster 2 (green), "Urban WasteWater (WW) treatment", conformed by 12 nodes with 209 co-occurrences, where characteristics of the NZ are taken advantage of, such as their low cost, chemical composition, and properties [112] in recovery processes of heavy metals [113] and other substances in municipal wastewater treatment plants [114], even considering these waters as new sources for other activities [115], with keywords "wastewater", "removal", and "ammonium".

Cluster 6 (light blue) "NZ HM adsorption" has seven nodes (154 co-occurrences); they evaluate the adsorption characteristics of zeolites under various parameters [98] and physical-mechanical properties [116] to solve problems, such as water contaminated with lead and cadmium [117], making use of preferential adsorption for HM classification [109], with keywords "heavy metal", "chabazite", and "phillipsite".

Cluster 10 (light pink), entitled "Ammonia selectivity by Ion Exchange (IE)" (three nodes, 132 co-occurrences), studies the ion exchange process in NZ [118] for the suppression of ammonia in surface waters [119], and comparisons with other processes [120], with keywords "ion exchange", "selectivity", "ammonia removal".

Other small clusters are cluster 8 (brown) "NZ use in Drinking Water (DW)", four nodes with 66 co-occurrences, which show studies concerning the efficiency of the removal of $\mathrm{NH}_{4}{ }^{+}$[121] and other pollutants in surface waters, taking advantage of the adsorption capacity of these minerals in water for human consumption [121], with keywords "water treatment", "drinking water", and "ammonium removal". This is followed by cluster 7 (orange) "NZ use in Soil Degradation (SD)" with five nodes and 45 co-occurrences. It is applied as a soil amendment method with natural zeolites to reduce and control the dynamics of nitrate and ammoniacal nitrogen [122], reducing the losses of gaseous $\mathrm{N}$ and favoring crop yield [123], promoting mitigation for, especially, agricultural soils [124], with keywords "degradation", "cation exchange", and "stabilization". Finally, in cluster 11 (turquoise), "Ammonia Adsorption Capacity (AC) by NZ" (three nodes, 40 co-occurrences), based on studies to determine the adsorption capacity of ammonia using natural zeolites [125], which project great potential and efficacy as microporous materials [126], with keywords "ammonia" and "adsorption capacity".

\subsubsection{Cited Authors Co-Citation Network}

VOSviewer software was used to construct the cited authors' co-citation map, shown in Figure 4. The intellectual structure of interest was studied (through the authors of the reference works) [69,127]; 947 authors had at least 20 citations per author, appearing in 10 clusters of different colors, with a total force of 928,935 .

The present analysis was carried out based on the number of cited author co-citations in descending order. A representative name was established for each cluster based on the similarity of the NZ topics, among the principal authors with the highest number of citations, obtaining groups that linked scientific fields, summarized in Table S3.

The following describes a clusters group with more than 5000 citations. Cluster 1 (red) is named "Ion removal in aqueous media", with 262 authors and 11,447 citations. It studies the effectiveness of natural zeolites in the removal of ions for different purposes, such as wastewater, and removal of basic dyes, among others; the leading researchers most cited are Wang, S., Wang, Y. and Li, Y. Cluster 2 (green) "Ion exchange of clinoptilolite" with 183 authors and 8402 citations. It consists of investigations based on clinoptilolite zeolite's beneficial properties; the authors include Loizidou, M., Inglezakis, V.J., and Ho, Y.S. Cluster 3 (blue) "Properties and applications of the NZ", with 177 authors and 7015 citations. The studies explore the variety of beneficial applications for different areas, including the environment, featuring prominent authors, such as Mumpton, F.A., Breck, D.W., and Misaelides, P. Cluster 4 (yellow) "NZ livestock applications", with 125 authors 
and 5289 citations. The NZ used for piggery waste treatment; authors include Borja, R., Sanchez, E., and Buszewski B.

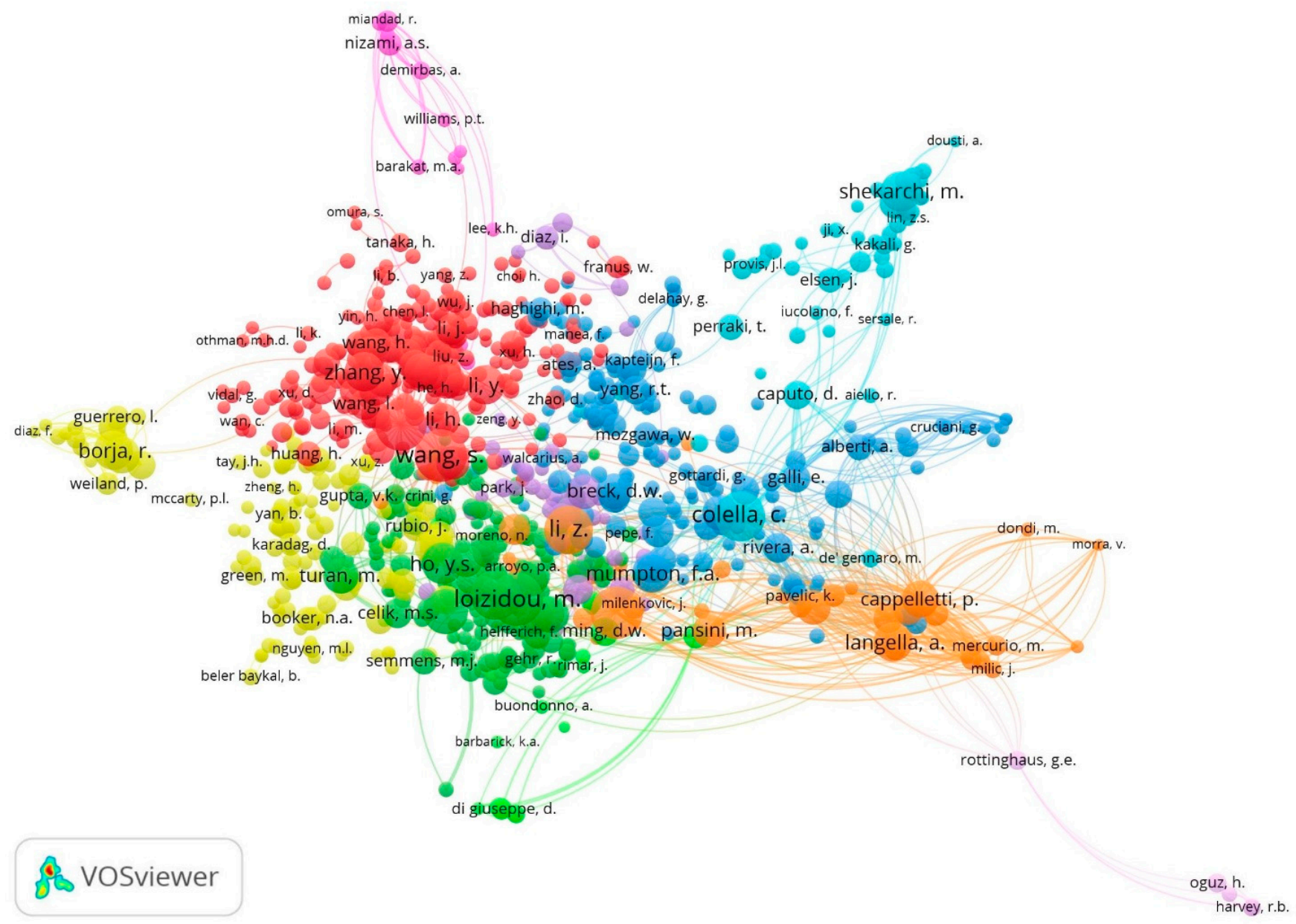

Figure 4. Co-citation bibliometric map of cited authors.

Other clusters with less than 5000 citations: Cluster 7 (orange) "Sorption kinetics of the NZ", with 44 authors and 2835 citations. This cluster uses the sorption property of $\mathrm{NZ}$ in nonpolar organic compounds, inorganic cations, and inorganic oxyanions. Authors include Bowman, R.S., Li, Z., and Langella, A. Cluster 6 (light blue), with 58 authors and 2525 citations, is based on natural zeolite sustainable applications in the construction area, defined as "NZ applications in construction". The authors include Colella, C., Shekarchi, M., and Ahmadi, B.

Cluster 5 (purple) "Sorption processes with NZ", with 59 authors and 2167 citations. The cluster focuses on studies concerning zeolite-rich tuffs for sorption processes; authors include Olguin, M.T., Hrenovic, J., Solache-Rios, M. Cluster 8 (green) "Agricultural uses of the NZ", with 19 nodes and 748 citations. In this cluster, the studies focus on soil remediation, authors include Ming, D.W., Passaglia, E., Rehakova, M. Cluster 9 (pink) “NZ applied to energy recovery", with 14 nodes and 463 citations. In this cluster, the studies look for economic and viable alternatives, such as NZ, to develop technologies applied to the energy area. Authors include Nizami, A.S., Rehan, M., and Barakat, M.A. Finally, Cluster 10 (light pink), with 6 authors and 222 citations, deals with topics such as the adsorption of organic compounds with NZ, represented by authors such as Rottinghaus, G.E., Oguz, H., and Harvey, R.B. 


\subsubsection{Journal Co-Citation Network}

The journal co-citation network allowed us to view shared citations of journal references through a global structure [128,129]; the VOSviewer software was used to observe the existing connections between related scientific journals through nodes and links with various connection forces [49,52].

Figure 5 shows journals with at least 20 citations, of which 195 journals obtained a total link strength of 283,940 , which shows the strength of the relationships between journals. The network shows six clusters, where the most cited journals are represented with larger nodes.

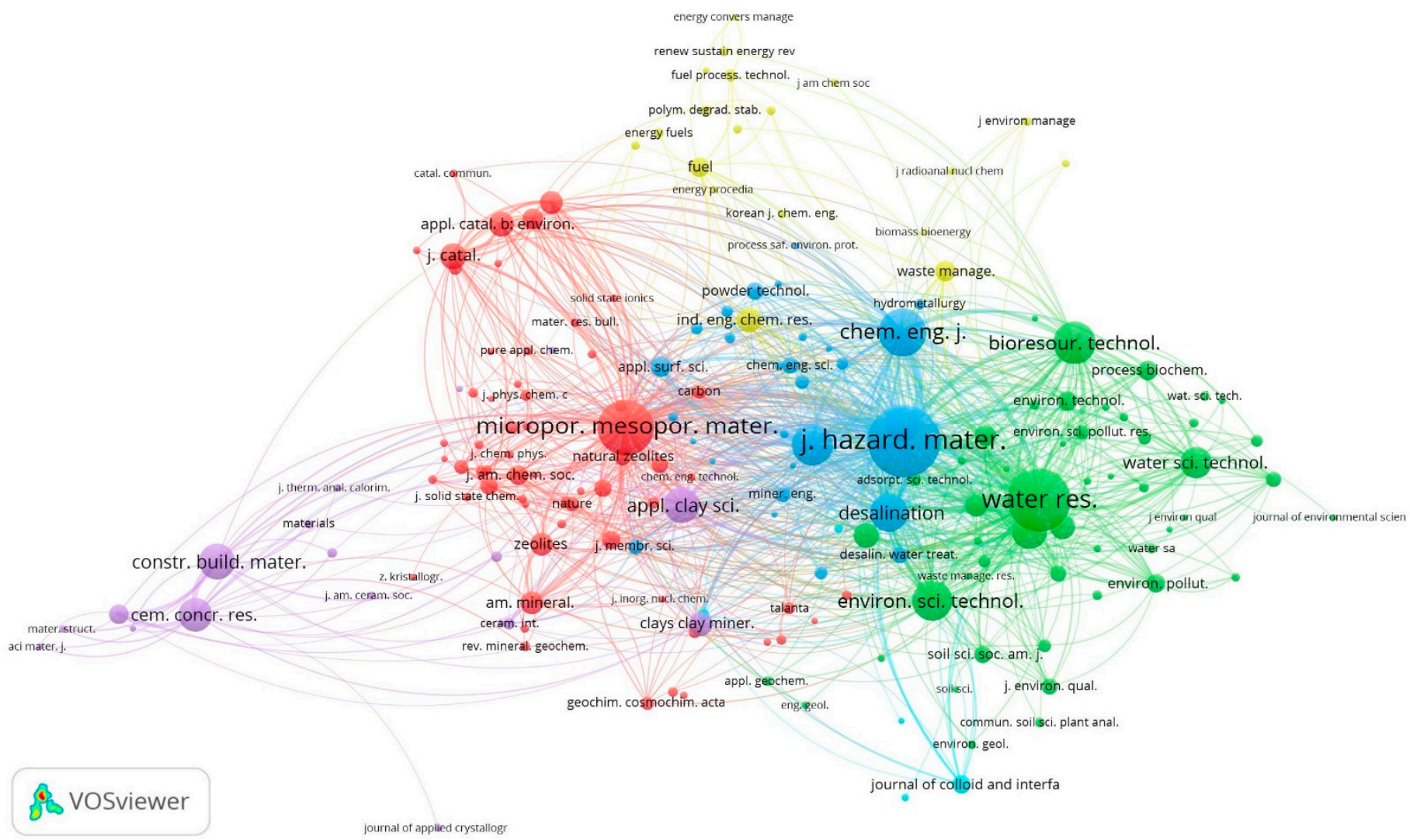

Figure 5. Bibliometric map of journal co-citation.

Further, Table S4 contains groups of journals ordered based on the number of cocitations, some of which are presented in Figure 5, along with the H-index.

Cluster 2 (green), defined as "Technologies applied to the environment", has 53 nodes and 7637 citations. A cluster that groups journals, such as Water Research, Bioresource Technology, and Environmental Science \& Technology, where Water Research is the cluster's representative journal, with an H-index of 285 and 1792 co-citations. Cluster 1 (red) "Catalysis of materials" is positioned with 63 nodes and 6284 citations, made up of journals such as Microporous and Mesoporous Materials, which is the main one, with an H-index of 151 (1444 co-citations), and the Journal of Catalysis. Cluster 6, "Materials and methods of separation" (light blue), has 15 nodes, 3911 citations, and journals such as the Journal of Hazardous Materials and Separation and Purification Technology, where the Journal of Hazardous Materials has the highest amount of co-group citations (2367) and an H-index of 260. Cluster 3 (blue), "Chemical processes and environment" with 22 nodes and 3650 citations is represented by journals such as Chemical Engineering Journal, Desalination, and the Journal of Colloid and Interface Science. Ranking in first place of this group, Chemical Engineering Journal, with an H-index 223, and 1025 co-citations. Cluster 5 "Construction waste management" 
(purple) presents 15 nodes and 2274 citations, where the journal with the highest number of co-citations is Applied Clay Science (603 co-citations; H-index: 119), followed by Construction and Building Materials. Lastly, cluster 4 (yellow), called "Energy and waste management", is made up of 22 nodes and 1437 citations, with representative journals such as Industrial $\mathcal{E}$ Engineering Chemistry Research (H-index 211; 294 co-citations) and Waste Management (H-index 145; 198 co-citations).

\section{Discussion}

An analysis of future trends in this line of research reflected that the studies of most significant interest, in the period 2000-2010, were those referring to the removal of heavy metal cations [87]; dye adsorption [92]; wastewater purification [91]; and ammonium and ammonia removal [79,130]. Likewise, in the 2010-2020 period, there was interest in removing ammonium from water, heavy metals, and purification of aqueous solutions, with natural or modified zeolites. Another topic of industrial interest was the improvement of construction materials, mainly for pozzolanic cement and mortars. Further developments in this study are expected in coming years.

The more significant numbers of scientific contributions from certain countries in this area, at the beginning, could have been attributed, in part, to discovering new potential commercial deposits of NZ (in the late 1950s). Moreover, since several countries in Europe, Asia, and North America were the leading suppliers in the NZ market, according to Roskill (a British firm specializing in market studies), in 1988, promoted research with natural zeolites in different areas [7]. However, currently, approximately 30 countries are leading producers, worldwide, of natural zeolites, including: China, Jordan, the Republic of Korea, Turkey, Japan, Slovakia, the United States, and Cuba [13]. China tops the list as the primary producer; however, it ranks second among the countries with the most publications and citations (see Table 1). Moreover, it has a close relationship with countries, such as Turkey, Iran, Australia, and the United States.

The analysis of author contributions reflected that the most cited authors did not necessarily have a large amount of research in this area. Most of the top 10 presented in Table 3 vary, with a range of 1 to 15 publications. The interesting thing about this is reflected in the number of citations that a single investigation can have, reflecting the scientific community's interest in specific topics. Surprisingly, China does not appear, being the most cited authors are from Turkey, Australia, and France.

At first glance, the most cited topics were those related to eliminating heavy metals in water for human consumption and wastewater [21,87]. Moreover, it is not surprising, given the accumulation of heavy metals in water and soils that seriously threaten health, food sources, and the environment, based on the need to apply practical, affordable, and, if possible, low-cost treatments [6].

Another aspect considered in Table 4 is TC, which specifies the number of total citations per article, and which differs from the ACI index (that calculates the number of citations of the article for its years of seniority). Some articles do not have a considerable TC due to the few years of publication, which puts them at a disadvantage compared to those with a higher TC. Table 4 shows that some articles that have a low TC do not necessarily have a lower ACI, as is the case with Yousef et al. (2011), with a TC = 337 (occupies the eighth place in the table), becoming the second most cited article per year, with an ACI of 33.7. On the other hand, with more in-depth analysis, it can be seen (in Table 2) that four thematic groups make up the top 10 journals: Microporous Materials, Water Research, Treatments, and Technologies. Microporous and Mesoporous Materials, the Journal of Hazardous Materials, and Construction, and Building Materials are highlighted. Despite being the most cited journals, some of the principal authors with the highest number of citations were not published in such journals. Only Lin J. has publications in Microporous and Mesoporous Materials; in the Journal of Hazardous Materials (Karapinar N., Erdem E., Donat R., Wang S., and Lin J.), and Construction and Building Materials (Shekarchi). Publications by the top 10 authors (Table 3) were also featured in other significant journals, such as Bioresource 
Technology and Water Research. However, curiously, only four of the most cited documents were published in one of the top 10 journals, the journal Water Research, where the document with the highest number of citations belongs to the Journal of Colloid and Interface Science.

The analyses of the intellectual structures of the bibliometric maps showed the networks and relationships present. Keyword co-occurrence mapping (see Figure 3) reveals that the term "natural zeolite" is the center of the structure, with 667 occurrences, followed by the term "zeolite" with 329 occurrences (Table 5), which have a stronger relationship with other terms, such as clinoptilolite, adsorption, ion exchange, and heavy metal. These agree, since the studies are based on properties, such as adsorption and ion exchange. The appearance of the term "clinoptilolite" among the principal relationships suggests that it is one of the most studied types of natural zeolites since it is considered one of the most abundant in nature [131], in addition to its properties, which make it stand out among other natural zeolites. Likewise, there are similar relationships between the cluster groups presented. Clusters 5 and 7 deal with soil care issues; clusters 1 and 6-thematic on heavy metals, and clusters 2,3 , and 8 focus on aqueous fluids. These close relationships between clusters give rise to topics focused on using natural zeolite properties to eliminate, retain, or reduce different pollutants.

After the previous analysis, in the author co-citation mapping (see Figure 4), the relationships between all clusters presented an intellectual structure focused on processes and applications in a great variety of areas, including energy. It was determined that the principal authors of this network with the highest number of co-citations are: Loizidou, M. from cluster 2 with 346 co-citations, with more robust links with author Inglezakis V. J.; Wang S. (cluster 1) with 339 co-citations-closely related to author Wang Y.; cluster 7 lead author Bowman R. S. (335 co-citations), showing the most robust relationship with Li Z.

Finally, the bibliometric mapping of journal co-citation (see Figure 5) exposed the thematic areas in which NZ research applied toward preserving the environment. The prominent journals with the highest number of co-citations are the Journal of Hazardous Materials (2367 co-citations, cluster 6), Water Research (1792 co-citations, cluster 2), and Microporous and Mesoporous Materials (1444 co-citations, cluster 1). The two leading journals have a strong relationship; moreover, they have the Chemical Engineering Journal in common, which is in the fifth position of the most cited (see Table 2). The journal Microporous and Mesoporous Materials has strong relationships with the Journal of Hazardous Materials, Water Research, and the Chemical Engineering Journal.

\section{Conclusions}

This article summarizes the investigations that applied natural zeolites as environmental remediation materials from 1973 to 2020.

Natural zeolites contain impurities, unlike synthetic zeolites, which are pure, and make NZ less efficient, but that, due to the cation exchange capacity, can be modified (i.e., by cation exchange- by adding certain cations to increase their effectiveness in certain specific uses). For example, they can be made highly bactericidal, i.e., by injecting the zeolite with $\mathrm{Ag}^{+}$cations through a prepared $\mathrm{AgNO}_{3}$ solution.

The results observed in the scientific production indicate a latent interest on the part of the literature, which is consistent, given the need for advances in the development of materials and methods that serve as environmental remedies in a world experiencing serious pollution problems. Moreover, a bibliometric analysis was carried out to understand the intellectual structure of this area, by evaluating scientific production, geographical distribution, and the contributions of frequently cited journals, authors, and documents. A total of 1582 publications, 81 countries, 564 journals, and 4436 authors were analyzed, reliably showing that natural zeolites have a wide range of application for protection, remediation, and environmental control issues.

Research in this study area has enhanced since the year 1997. The authors of these publications are mainly in Europe or Asia, followed by America and Oceania. The Eurasian 
continent provided the greatest scientific contributions in this area, with $76 \%$ of the publications. Countries such as Turkey, China, and Iran topped the list.

The authors with the highest number of citations in the area are Karapinar N. and Erdem E. from the Pamukkale Üniversitesi institute (Turkey), and Wang S., the University of Adelaide in Australia. According to the number of publications, the journals that lead these contributions in the study area are Microporous and Mesoporous Materials, Construction and Building Materials, and the Journal of Hazardous Materials. The main processes investigated and linked to these journals include important research of NZ used as nanomaterials.

The cognitive structure, visualized by the bibliometric analysis, is presented in the cooccurrence maps of author keywords and the co-citation of authors and journals, revealing the most relevant topics of the study area, focusing on the use, processes, and applications of natural zeolites to preserve the environment. We consider that, presenting a study of natural zeolites with a bibliometric approach, contributes to the scientific community by analyzing the intellectual structure, allowing us to extract experiences from researchers in this field of study. Experiences are transmitted concisely and briefly about countries, institutions, and authors involved, as well as the topics and research themes. This study is a contribution to the young researchers in this area of study.

However, the research has certain limitations: (i) it considers only one type of document (articles); (ii) the preference for only one language (English); (iii) it does not include several databases, it uses only one (Scopus); and (iv) it applies a single approach when examining a particular field of study.

Finally, according to the analyses carried out, further developments in this line of research will continue to grow, i.e., in regards to water treatment (drinking water, wastewater, and greywater), removal of heavy metals, ammonium, ammonia, and construction.

Supplementary Materials: The following are available online at https:/ /www.mdpi.com/article/ 10.3390/su13116378/s1, Table S1: Top 10 most cited countries in the study field, Table S2: Detail of the Keywords with the highest Co-occurrence, Table S3: Detail of the authors with the highest Co-citation, Table S4: Detail of the journals with the highest number of Citation.

Author Contributions: Conceptualization: F.M.-C., N.M.-B., P.C.-M., and K.J.-F; methodology: N.M.B., F.M.-C., and K.J.-F.; research: N.M.-B., K.J.-F., and F.M.-C.; writing—original draft preparation: N.M.-B. and K.J.-F.; writing — reviewing and editing: N.M.-B., F.M.-C., P.C.-M., and K.J.-F.; Monitoring: F.M.-C. and P.C.-M. All authors have read and agreed to the published version of the manuscript.

Funding: This research received no external funding.

Institutional Review Board Statement: Not applicable.

Informed Consent Statement: Not applicable.

Data Availability Statement: The information described in this article was compiled in the Scopus database and is available at DOI:10.5281/zenodo.4770933. Any questions should be submitted to the corresponding author.

Acknowledgments: This work was made possible by the valuable collaboration of the ESPOL research project: "Register of geological and mining heritage and its incidence in the defense and preservation of geodiversity in Ecuador" under grant no. CIPAT-01-2018; and the support of NOVA Science Research Associates. The authors are grateful for the collaboration of the novel researcher María Fernanda Jaya for her help in the process of proofreading and editing the article.

Conflicts of Interest: The authors declare no conflict of interest.

\section{Abbreviations}

The following abbreviations were used in this manuscript: 


$\begin{array}{ll}\text { AC } & \text { Adsorption Capacity } \\ \text { ACI } & \text { Annual Citation Index } \\ \text { AT } & \text { Number of Articles } \\ \text { AMD } & \text { Acid Mine Drainage } \\ \text { AW } & \text { Acid Water } \\ \text { CSV } & \text { Comma-Separated Values } \\ \text { DW } & \text { Drinking Water } \\ \text { HI } & \text { H-Index } \\ \text { HM } & \text { Heavy Metals } \\ \text { HOCs } & \text { Hydrophobic Organic Pollutants } \\ \text { IE } & \text { Ion Exchange } \\ \text { MOCZ } & \text { Manganese oxide-coated zeolite } \\ \text { NOC } & \text { Non-ionic Organic Pollutants } \\ \text { NZ } & \text { Natural Zeolites } \\ \text { PAHs } & \text { Polycyclic Aromatic Hydrocarbons } \\ \text { PBDEs } & \text { Polybrominated Diphenyl Ethers } \\ \text { PTE } & \text { Potentially toxic elements } \\ \text { R } & \text { Rank } \\ \text { SD } & \text { Soil Degradation } \\ \text { SJR } & \text { SCImago Journal Rank } \\ \text { TC } & \text { Total number of citations } \\ \text { WW } & \text { WasteWater }\end{array}$

\section{References}

1. Cruz-Guzman, M. La Contaminación de Suelos y Aguas: Su Prevención con Nuevas Sustancias Naturales; Universidad d Sevilla: Sevilla, Spain, 2007.

2. Inglezakis, V.J.; Loizidou, M.D.; Grigoropoulou, H.P. Ion exchange of $\mathrm{Pb}^{2+}, \mathrm{Cu}^{2+}, \mathrm{Fe}^{3+}$, and $\mathrm{Cr}^{3+}$ on natural clinoptilolite: Selectivity determination and influence of acidity on metal uptake. J. Colloid Interface Sci. 2003, 261, 49-54. [CrossRef]

3. Reyes, Y.C.; Vergara, I.; Torres, O.E.; Díaz, M.; González, E.E. Heavy metals contamination: Implications for health and food safety. Ing. Investig. Desarro. 2016, 16, 66-77. Available online: https://dialnet.unirioja.es/servlet/articulo?codigo=6096110 (accessed on 2 November 2020).

4. ZHuang, Z.; Pan, X.-D.; Wu, P.-G.; Han, J.-L.; Chen, Q. Heavy metals in vegetables and the health risk to population in Zhejiang, China. Food Control. 2014, 36, 248-252. [CrossRef]

5. SLin, H.; Juang, R.S. Heavy metal removal from water by sorption using surfactant-modified montmorillonite. J. Hazard. Mater. 2002, 92, 315-326. [CrossRef]

6. Mumpton, F.A. La roca magica: Uses of natural zeolites in agriculture and industry. Proc. Natl. Acad. Sci. USA 1999, 96, 3463-3470. [CrossRef] [PubMed]

7. Morante, F. Las Zeolitas de la Costa De Ecuador (Guayaquil): Geología, Caracterización y Aplicaciones. Ph.D. Thesis, E.T.S.I. Minas (UPM), Madrid, Spain, 2004.

8. Calvo, B.; Canoira, L.; Morante, F.; Martínez-Bedia, J.M.; Vinagre, C.; García-González, J.-E.; Elsen, J.; Alcántara, R. Continuous elimination of $\mathrm{Pb}^{2+}, \mathrm{Cu}^{2+}, \mathrm{Zn}^{2+}, \mathrm{H}^{+}$and $\mathrm{NH}^{4+}$ from acidic waters by ionic exchange on natural zeolites. J. Hazard. Mater. 2009, 166, 619-627. [CrossRef]

9. An, W.; Zhou, X.; Liu, X.; Chai, P.; Kuznicki, T.; Kuznicki, S. Natural zeolite clinoptilolite-phosphate composite Membranes for water desalination by pervaporation. J. Membr. Sci. 2014, 470, 431-438. [CrossRef]

10. Rege, S.U.; Yang, R.T.; Qian, K.; Buzanowski, M.A. Air-prepurification by pressure swing adsorption using single/layered beds. Chem. Eng. Sci. 2001, 56, 2745-2759. [CrossRef]

11. An, W.; Swenson, P.; Wu, L.; Waller, T.; Ku, A.; Kuznicki, S.M. Selective separation of hydrogen from C1/C2 hydrocarbons and CO2 through dense natural zeolite membranes. J. Membr. Sci. 2011, 369, 414-419. [CrossRef]

12. Parham, W. Natural zeolites: Some potential agricultural applications for developing countries. Nat. Resour. Forum 1989, 13, 107-115. [CrossRef]

13. Costafreda, J.; Sanchez, M.; Velazquez, C.; Govea, P.; Tobon, I.; Gutierrez, A.; Vasquez, B.; Andres, L.; Alfonso, D.; Luis, J.; et al. Las Zeolitas Naturales de Iberoamérica; Fundación Gómez Pardo: Madrid, Spain, 2018.

14. Moscou, L. Chapter 1 The Zeolite Scene. Stud. Surf. Sci. Catal. 1991, 58, 1-12. [CrossRef]

15. Breck, D.W. Zeolite Molecular Sieves: Structure, Chemistry and Use; John Wiley and Sons: Hoboken, NJ, USA, 1973.

16. Waisberg, M.; Joseph, P.; Hale, B.; Beyersmann, D. Molecular and cellular mechanisms of cadmium carcinogenesis. Toxicology 2003, 192, 95-117. [CrossRef]

17. Franco, L.F.L.; Muñoz, P.T.L.; Garcia, F.G.M. Los riesgos de los metales pesados en la salud humana y animal. Biotecnol. Sect. Agropecu. Agroind. 2016, 14, 145. [CrossRef]

18. Kothandaraman, V. Industrial Water Pollution Control. JAWRA J. Am. Water Resour. Assoc. 1969, 5, 73-74. [CrossRef] 
19. Guo, X.; Zeng, L.; Jin, X. Advanced regeneration and fixed-bed study of ammonium and potassium removal from anaerobic digested wastewater by natural zeolite. J. Environ. Sci. 2013, 25, 954-961. [CrossRef]

20. Hailu, Y.; Tilahun, E.; Brhane, A.; Resky, H.; Sahu, O. Ion exchanges process for calcium, magnesium and total hardness from ground water with natural zeolite. Groundw. Sustain. Dev. 2019, 8, 457-467. [CrossRef]

21. Blanchard, G.; Maunaye, M.; Martin, G. Removal of heavy metals from waters by means of natural zeolites. Water Res. 1984, 18, 1501-1507. [CrossRef]

22. Kiurski, J.; Adamović, S.; Oros, I.; Krstić, J.; Miloradov, M.V. The removal efficiency of heavy metals from spent printing developer. Carpathian J. Earth Environ. Sci. 2012, 7, 5-16.

23. Dwairi, R.A.A.; Al-Rawajfeh, A.E. Removal of cobalt and nickel from wastewater by using jordan low-cost zeolite and bentonite. J. Univ. Chem. Technol. Metall. 2012, 47,69-76.

24. Galletti, C.; Dosa, M.; Russo, N.; Fino, D. $\mathrm{Zn}^{2+}$ and $\mathrm{Cd}^{2+}$ removal from wastewater using clinoptilolite as adsorbent. Environ. Sci. Pollut. Res. 2020. [CrossRef]

25. Díaz, I. Environmental uses of zeolites in Ethiopia. Catal. Today 2017, 285, 29-38. [CrossRef]

26. Mustelier, J.L.C. Geología, caracterización y aplicaciones de las rocas zeolíticas del complejo volcánico de Cabo de Gata (Almería). Ph.D. Thesis, E.T.S.I. Minas, Madrid, Spain, 2008.

27. Colella, C. Environmental Applications of Natural Zeolitic Materials Based on Their Ion Exchange Properties. In Natural Microporous Materials in Environmental Technology; Springer: Dordrecht, The Netherlands, 1999; pp. $207-224$.

28. Mier, M.V.; Callejas, R.L.; Gehr, R.; Cisneros, B.E.J.; Alvarez, P. Heavy metal removal with mexican clinoptilolite. Water Res. 2001, 35, 373-378. [CrossRef]

29. Shavandi, M.; Haddadian, Z.; Ismail, M.; Abdullah, N.; Abidin, Z. Removal of Fe(III), Mn(II) and Zn(II) from palm oil mill effluent (POME) by natural zeolite. J. Taiwan Inst. Chem. Eng. 2012, 43, 750-759. [CrossRef]

30. RMalekian, R.; Abedi-Koupai, J.; Eslamian, S.S.; Mousavi, S.F.; Abbaspour, K.C.; Afyuni, M. Ion-exchange process for ammonium removal and release using natural Iranian zeolite. Appl. Clay Sci. 2011, 51, 323-329. [CrossRef]

31. Fu, H.; Li, Y.; Yu, Z.; Shen, J.; Li, J.; Zhang, M.; Ding, T.; Xu, L.; Lee, S.S. Ammonium removal using a calcined natural zeolite modified with sodium nitrate. J. Hazard. Mater. 2020, 393, 122481. [CrossRef] [PubMed]

32. Tomečková, V.; Lichardusová, L.; Komanicky, V.; Pelegrinová, D. The Spectrofluorometric Monitoring of Water Purification by Natural Alternatives. Spectrosc. Lett. 2012, 45, 447-451. [CrossRef]

33. Echevarría, M.S.; Déniz, R.D.T.; Castellanos, E.M.; A Sherbakov, G.; Moya, J.J.R. Uses of natural zeolite in the removal of Pb ${ }^{2+}$ from contaminated water. Eclética Química J. 1997, 22, 15-22. [CrossRef]

34. Swenson, P.; Tanchuk, B.; Bastida, E.; An, W.; Kuznicki, S.M. Water desalination and de-oiling with natural zeolite membranesPotential application for purification of SAGD process water. Desalination 2012, 286, 442-446. [CrossRef]

35. Meshko, V.D.; Markovska, L.T.; Minceva, M.B.; Cibulic, V.V. Modelling of a fixed bed adsorption column for waste water treatment. J. Serb. Chem. Soc. 1998, 63, 891-901.

36. Pucarevic, M.; Stojic, N.; Kuzmanovski, I. Removal of pesticides from water using zeolites. Kuwait J. Sci. 2017, 44, 99-105.

37. Markovic, R.; Gardic, V.; Obradovic, L.; Djordjievski, S.; Stevanović, Z.; Stevanovic, J.; Gvozdenovic, M. The Application of a Natural Zeolite for Acid Mine Drainage Purification. Mater. Trans. 2015, 56, 2053-2057. [CrossRef]

38. Baykara, H.; Martinez, M.C.; Rey, D.V.; Urbina, D.S.; Paredes, C.; Rigail-Cedeño, A.; Aviles, M.O. Preparation and Determination of Antimicrobial Property of Cation-Exchanged Ecuadorian Natural Zeolite to be Used as Filler for Polyethylene and Polypropylene Matrices. J. Polym. Environ. 2017, 26, 2566-2578. [CrossRef]

39. Chen, Y.; Yu, W.; Jin, L.; Wang, Q.; Yin, J.; Lin, J.; Li, J.-Y. Stabilization of hydrophobic organic contaminants in sediments by natural zeolites: Bioavailability-based assessment of efficacy using equilibrium passive sampling. J. Soils Sediments 2019, 19, 3898-3907. [CrossRef]

40. Ghiaci, M.; Abbaspur, A.; Kia, R.; Seyedeyn-Azad, F. Equilibrium isotherm studies for the sorption of benzene, toluene, and phenol onto organo-zeolites and as-synthesized MCM-41. Sep. Purif. Technol. 2004, 40, 217-229. [CrossRef]

41. Cappelletti, P.; Colella, A.; Langella, A.; Mercurio, M.; Catalanotti, L.; Monetti, V.; de Gennaro, B. Use of surface modified natural zeolite (SMNZ) in pharmaceutical preparations Part 1. Mineralogical and technological characterization of some industrial zeolite-rich rocks. Microporous Mesoporous Mater. 2017, 250, 232-244. [CrossRef]

42. Faghihian, H.; Marageh, M.G.; Kazemian, H. The use of clinoptilolite and its sodium form for removal of radioactive cesium, and strontium from nuclear wastewater and $\mathrm{Pb}^{2+}, \mathrm{Ni}^{2+}, \mathrm{Cd}^{2+}, \mathrm{Ba}^{2+}$ from municipal wastewater. Appl. Radiat. Isot. 1999, 50, 655-660. [CrossRef]

43. Osmanlioglu, A.E. Treatment of radioactive liquid waste by sorption on natural zeolite in Turkey. J. Hazard. Mater. 2006, 137, 332-335. [CrossRef]

44. Chelishchev, N.F. Use of natural zeolites at Chernobyl. Nat. Zeolites 1995, 93, 525-532. Available online: https://ci.nii.ac.jp/naid/ 20001587662 (accessed on 5 November 2020).

45. Malczyk, P. Mercury inactivation in contaminated soil using natural zeolites of the clinoptilolite type. Fresenius Environ. Bull. 2009, 18, 1090-1093.

46. Taheri-Sodejani, H.; Ghobadinia, M.; Tabatabaei, S.-H.; Kazemian, H. Using natural zeolite for contamination reduction of agricultural soil irrigated with treated urban wastewater. Desalination Water Treat. 2014, 54, 2723-2730. [CrossRef] 
47. Tranfield, D.; Denyer, D.; Smart, P. Towards a Methodology for Developing Evidence-Informed Management Knowledge by Means of Systematic Review. Br. J. Manag. 2003, 14, 207-222. [CrossRef]

48. Fahimnia, B.; Sarkis, J.; Davarzani, H. Green supply chain management: A review and bibliometric analysis. Int. J. Prod. Econ. 2015, 162, 101-114. [CrossRef]

49. Carrión-Mero, P.; Montalván-Burbano, N.; Paz-Salas, N.; Morante-Carballo, F. Volcanic Geomorphology: A Review of Worldwide Research. Geosciences 2020, 10, 347. [CrossRef]

50. Zupic, I.; Čater, T. Bibliometric methods in management and organization. Organ. Res. Methods 2014, 18, 429-472. [CrossRef]

51. Herrera-Franco, G.; Montalván-Burbano, N.; Carrión-Mero, P.; Jaya-Montalvo, M.; Gurumendi-Noriega, M. Worldwide Research on Geoparks through Bibliometric Analysis. Sustainability 2021, 13, 1175. [CrossRef]

52. Van Eck, N.J.; Waltman, L. Software survey: VOSviewer, a computer program for bibliometric mapping. Scientometrics 2010, 84, 523-538. [CrossRef]

53. Ogawa, T.; Iyoki, K.; Fukushima, T.; Kajikawa, Y. Landscape of Research Areas for Zeolites and Metal-Organic Frameworks Using Computational Classification Based on Citation Networks. Materials 2017, 10, 1428. [CrossRef]

54. Reháková, M.; Sopková, A.; Casciola, M.; Failla, S. A study of the silver form of a natural zeolitic material of the clinoptilolite type. J. Incl. Phenom. Mol. Recognit. Chem. 1994, 20, 233-240. [CrossRef]

55. Syamsiah, S.; Hadi, I.S. Adsorption cycles and effect of microbial population on phenol removal using natural zeolit. Sep. Purif. Technol. 2004, 34, 125-133. [CrossRef]

56. Andres, A. Measuring Academic Research. Meas. Acad. Res. 2009. [CrossRef]

57. Pico-Saltos, R.; Garz, J. Research Trends in Career Success: A Bibliometric Review. Sustainability 2021, 13, 4625. [CrossRef]

58. Baas, J.; Schotten, M.; Plume, A.; Côté, G.; Karimi, R. Scopus as a curated, high-quality bibliometric data source for academic research in quantitative science studies. Quant. Sci. Stud. 2020, 1, 377-386. [CrossRef]

59. Del Río-Rama, M.; Maldonado-Erazo, C.; Álvarez-García, J.; Durán-Sánchez, A. Cultural and Natural Resources in Tourism Island: Bibliometric Mapping. Sustainability 2020, 12, 724. [CrossRef]

60. Ruban, D.A.; Ponedelnik, A.A.; Yashalova, N.N. Megaclasts: Term Use and Relevant Biases. Geosciences 2018, 9, 14. [CrossRef]

61. Meseguer-Sánchez, V.; Abad-Segura, E.; Belmonte-Ureña, L.J.; Molina-Moreno, V. Examining the Research Evolution on the Socio-Economic and Environmental Dimensions on University Social Responsibility. Int. J. Environ. Res. Public Health 2020, 17, 4729. [CrossRef] [PubMed]

62. Najmi, A.; Rashidi, T.H.; Abbasi, A.; Waller, T. Reviewing the transport domain: An evolutionary bibliometrics and network analysis. Scientometrics 2017, 110, 843-865. [CrossRef]

63. Aznar-Sánchez, J.A.; Velasco-Muñoz, J.F.; Belmonte-Ureña, L.J.; Manzano-Agugliaro, F. The worldwide research trends on water ecosystem services. Ecol. Indic. 2019, 99, 310-323. [CrossRef]

64. Van Eck, N.J.; Waltman, L. Visualizing Bibliometric Networks. In Measuring Scholarly Impact; Springer International Publishing: Cham, Switzerland, 2014; pp. 285-320.

65. Van Eck, N.J.; Waltman, L.; Noyons, E.C.M.; Buter, R.K. Automatic term identification for bibliometric mapping. Scientometrics 2010, 82, 581-596. [CrossRef]

66. Chandra, Y. Mapping the evolution of entrepreneurship as a field of research (1990-2013): A scientometric analysis. PLoS ONE 2018, 13, e0190228. [CrossRef]

67. Herrera-Franco, G.; Montalván-Burbano, N.; Carrión-Mero, P.; Bravo-Montero, L. Worldwide Research on Socio-Hydrology: A Bibliometric Analysis. Water 2021, 13, 1283. [CrossRef]

68. Van Eck, N.J.; Waltman, L. Citation-based clustering of publications using CitNetExplorer and VOSviewer. Scientometrics 2017, 111, 1053-1070. [CrossRef] [PubMed]

69. Herrera-Franco, G.; Montalván-Burbano, N.; Carrión-Mero, P.; Apolo-Masache, B.; Jaya-Montalvo, M. Research Trends in Geotourism: A Bibliometric Analysis Using the Scopus Database. Geosciences 2020, 10, 379. [CrossRef]

70. Li, J.; Jovanovic, A.; Klimek, P.; Guo, X. Bibliometric analysis of fracking scientific literature. Scientometrics 2015, 105, 1273-1284. [CrossRef]

71. Briones-Bitar, J.; Carrión-Mero, P.; Montalván-Burbano, N.; Morante-Carballo, F. Rockfall Research: A Bibliometric Analysis and Future Trends. Geosciences 2020, 10, 403. [CrossRef]

72. Montalván-Burbano, N.; Pérez-Valls, M.; Plaza-Úbeda, J. Analysis of scientific production on organizational innovation. Cogent Bus. Manag. 2020, 7, 1745043. [CrossRef]

73. Zhu, B.; Fan, H.; Xie, B.; Su, R.; Zhou, C.; He, J. Mapping the Scientific Research on Healthcare Workers' Occupational Health: A Bibliometric and Social Network Analysis. Int. J. Environ. Res. Public Health 2020, 17, 2625. [CrossRef]

74. Durán-Sánchez, A.; del Río-Rama, M.d.; Álvarez-García, J.; García-Vélez, D.F. Mapping of scientific coverage on education for Entrepreneurship in Higher Education. J. Enterprising Communities 2019, 13, 84-104. [CrossRef]

75. Vdovina, E.D.; Radyuk, R.I.; Sultanov, A.S.; Aripov, E.A. Use of natural zeolites of uzbekistan for the purification of low activity sewage. II. Sorption of radioactive cobalt. Sov. Radiochem. 1977, 19, 155-157.

76. Sims, R.C.; Little, L.W. Enhanced Nitrification by Addition of Clinoptilolite to Tertiary Activated Sludge Units. Environ. Lett. 1973, 4, 27-34. [CrossRef]

77. Semmens, M.; Martin, W. The influence of pretreatment on the capacity and selectivity of clinoptilolite for metal ions. Water Res. 1988, 22, 537-542. [CrossRef] 
78. Ćurković, L.; Cerjan-Stefanović, Š.; Filipan, T. Metal ion exchange by natural and modified zeolites. Water Res. 1997, 31, 1379-1382. [CrossRef]

79. Saltalı, K.; Sarı, A.; Aydın, M. Removal of ammonium ion from aqueous solution by natural Turkish (Yıldızeli) zeolite for environmental quality. J. Hazard. Mater. 2007, 141, 258-263. [CrossRef] [PubMed]

80. Wang, S.; Ariyanto, E. Competitive adsorption of malachite green and Pb ions on natural zeolite. J. Colloid Interface Sci. 2007, 314, 25-31. [CrossRef] [PubMed]

81. Llanes-Monter, M.M.; Olguín, M.T.; Solache-Ríos, M.J. Lead sorption by a Mexican, clinoptilolite-rich tuff. Environ. Sci. Pollut. Res. 2007, 14, 397-403. [CrossRef]

82. Motsi, T.; Rowson, N.; Simmons, M. Adsorption of heavy metals from acid mine drainage by natural zeolite. Int. J. Miner. Process. 2009, 92, 42-48. [CrossRef]

83. Li, H.; Shi, W.-Y.; Shao, H.-B.; Shao, M.-A. The remediation of the lead-polluted garden soil by natural zeolite. J. Hazard. Mater. 2009, 169, 1106-1111. [CrossRef] [PubMed]

84. Zou, W.; Zhao, L.; Han, R. Removal of Uranium (VI) by Fixed Bed Ion-exchange Column Using Natural Zeolite Coated with Manganese Oxide. Chin. J. Chem. Eng. 2009, 17, 585-593. [CrossRef]

85. Yousef, R.I.; El-Eswed, B.; Al-Muhtaseb, A.H. Adsorption characteristics of natural zeolites as solid adsorbents for phenol removal from aqueous solutions: Kinetics, mechanism, and thermodynamics studies. Chem. Eng. J. 2011, 171, 1143-1149. [CrossRef]

86. Mansouri, N.; Rikhtegar, N.; Panahi, H.A.; Atabi, F.; Shahraki, B.K. Porosity, characterization and structural properties of natural zeolite-Clinoptilolite-As a sorbent. Environ. Prot. Eng. 2013, 39, 139-152. [CrossRef]

87. Erdem, E.; Karapinar, N.; Donat, R. The removal of heavy metal cations by natural zeolites. J. Colloid Interface Sci. 2004, 280, 309-314. [CrossRef]

88. Meshko, V.; Markovska, L.; Mincheva, M.; Rodrigues, A. Adsorption of basic dyes on granular acivated carbon and natural zeolite. Water Res. 2001, 35, 3357-3366. [CrossRef]

89. MBissen, M.; Frimmel, F.H. Arsenic-A Review. Part II: Oxidation of Arsenic and its Removal in Water Treatment. Acta Hydrochim. Hydrobiol. 2003, 31, 97-107. [CrossRef]

90. Perić, J.; Trgo, M.; Medvidović, N.V. Removal of zinc, copper and lead by natural zeolite-A comparison of adsorption isotherms. Water Res. 2004, 38, 1893-1899. [CrossRef]

91. Álvarez-Ayuso, E. Purification of metal electroplating waste waters using zeolites. Water Res. 2003, 37, 4855-4862. [CrossRef]

92. Han, R.; Zhang, J.; Han, P.; Wang, Y.; Zhao, Z.; Tang, M. Study of equilibrium, kinetic and thermodynamic parameters about methylene blue adsorption onto natural zeolite. Chem. Eng. J. 2009, 145, 496-504. [CrossRef]

93. Montalván-Burbano, N.; Velastegui-Montoya, A.; Gurumendi-Noriega, M.; Morante-Carballo, F.; Adami, M. Worldwide Research on Land Use and Land Cover in the Amazon Region. Sustainability 2021, 13, 6039. [CrossRef]

94. Szollosi-Mota, A.; Prodan, M.; Ghicioi, E.; Nalboc, I.; Moldovan, C. Heavy metals removal from mining drainage acid water by use of natural zeolites. Environ. Eng. Manag. J. 2017, 16, 1383-1388. [CrossRef]

95. Varvara, S.; Popa, M.; Bostan, R.; Damian, G. Preliminary considerations on the adsorption of heavy metals from acidic mine drainage using natural zeolite. J. Environ. Prot. Ecol. 2013, 14, 1506-1514.

96. Buenaño, X.; Canoira, L.; Sánchez, D.M.; Costafreda, J. Zeolitic tuffs for acid mine drainage (AMD) treatment in Ecuador: Breakthrough curves for $\mathrm{Mn}^{2+}, \mathrm{Cd}^{2+}, \mathrm{Cr}^{3+}, \mathrm{Zn}^{2+}$, and $\mathrm{Al}^{3+}$. Environ. Sci. Pollut. Res. 2017, 24, 6794-6806. [CrossRef] [PubMed]

97. Gaikwad, R.W.; Misal, S.A.; Dhirendra; Gupta, D.V. Removal of metal from acid mine drainage (AMD) by using natural zeolite of Nizarneshwar Hills of Western India. Arab. J. Geosci. 2009, 4, 85-89. [CrossRef]

98. Nasrabadi, M.; Omid, M.H.; Mazdeh, A.M.; Shahriari, T. Cadmium adsorption by natural zeolite in a circular flume. Int. J. Environ. Technol. Manag. 2018, 21, 174. [CrossRef]

99. Ivanova, E.P.; Kostova, M.A.; Koumanova, B.K. Kinetics of water and alcohol vapors adsorption on natural zeolite. Asia-Pacific J. Chem. Eng. 2009, 5, 869-881. [CrossRef]

100. Smical, I. Sorption kinetics of $\mathrm{pbspi}^{2+}$, cuspi $^{2+}$ and znspi ${ }^{2+}$ ions by natural zeolites from maramures county (northern romania): Potential application in wastewater reuse. AACL Bioflux 2011, 4, 481-489.

101. Vrînceanu, N.; Motelică, D.; Dumitru, M.; Calciu, I.; Tănase, V.; Preda, M. Assessment of using bentonite, dolomite, natural zeolite and manure for the immobilization of heavy metals in a contaminated soil: The Copșa Mică case study (Romania). Catena 2019, 176, 336-342. [CrossRef]

102. Contin, M.; Miho, L.; Pellegrini, E.; Gjoka, F.; Shkurta, E. Effects of natural zeolites on ryegrass growth and bioavailability of Cd, $\mathrm{Ni}, \mathrm{Pb}$, and $\mathrm{Zn}$ in an Albanian contaminated soil. J. Soils Sediments 2019, 19, 4052-4062. [CrossRef]

103. Janoš, P.; Vávrová, J.; Herzogová, L.; Pilařová, V. Effects of inorganic and organic amendments on the mobility (leachability) of heavy metals in contaminated soil: A sequential extraction study. Geoderma 2010, 159, 335-341. [CrossRef]

104. Doula, M.K.; Elaiopoulos, K.; Kavvadias, V.A.; Mavraganis, V. Use of clinoptilolite to improve and protect soil quality from the disposal of olive oil mills wastes. J. Hazard. Mater. 2012, 207-208, 103-110. [CrossRef] [PubMed]

105. Asl, M.K.; Hasani, A.H.; Naserkhaki, E. Evaluation of nitrate removal from water using activated carbon and clinoptilolite by adsorption method. Biosci. Biotechnol. Res. Asia 2016, 13, 1045-1054. [CrossRef]

106. Polloni-Silva, J.; Valdehita, A.; Fracácio, R.; Navas, J.M. Remediation efficiency of three treatments on water polluted with endocrine disruptors: Assessment by means of in vitro techniques. Chemosphere 2017, 173, 267-274. [CrossRef] 
107. Nagaiah, E.; Sonkamble, S.; Mondal, N.C.; Ahmed, S. Natural zeolites enhance groundwater quality: Evidences from Deccan basalts in India. Environ. Earth Sci. 2017, 76, 536. [CrossRef]

108. Margeta, K.; Stefanović, Š.C.; Kaučič, V.; Logar, N.Z. The potential of clinoptilolite-rich tuffs from Croatia and Serbia for the reduction of toxic concentrations of cations and anions in aqueous solutions. Appl. Clay Sci. 2015, 116-117, 111-119. [CrossRef]

109. Liu, X.; Tian, R.; Ding, W.; He, Y.; Li, H. Adsorption selectivity of heavy metals by Na-clinoptilolite in aqueous solutions. Adsorption 2019, 25, 747-755. [CrossRef]

110. Pepe, F.; de Gennaro, B.; Aprea, P.; Caputo, D. Natural zeolites for heavy metals removal from aqueous solutions: Modeling of the fixed bed $\mathrm{Ba}^{2+} / \mathrm{Na}^{+}$ion-exchange process using a mixed phillipsite/chabazite-rich tuff. Chem. Eng. J. 2013, 219, 37-42. [CrossRef]

111. Seliman, A.F.; Borai, E.H. Utilization of natural chabazite and mordenite as a reactive barrier for immobilization of hazardous heavy metals. Environ. Sci. Pollut. Res. 2011, 18, 1098-1107. [CrossRef]

112. Torosyan, G.; Matevosyan, G.; Harutyunyan, S. Use of Natural Materials for Wastewater Treatment \& Improvement of Water Quality. In Advanced Water Supply and Wastewater Treatment: A Road to Safer Society and Environment; NATO Science for Peace and Security Series C: Environmental Security; Hlavinek, P., Winkler, I., Marsalek, J., Mahrikova, I., Eds.; Springer: Dordrecht, The Netherlands, 2011; Volume 106, pp. 171-180.

113. Filatova, E.G.; Pomazkina, O.I.; Pozhidaev, Y.N. Development of the zeolite-sorption process for electroplating wastewater treatment. J. Water Chem. Technol. 2014, 36, 303-308. [CrossRef]

114. Ellersdorfer, M. The ion-exchanger-loop-stripping process: Ammonium recovery from sludge liquor using NaCl-treated clinoptilolite and simultaneous air stripping. Water Sci. Technol. 2018, 77, 695-705. [CrossRef]

115. Yousefi, A.; Matavos-Aramyan, S. Mix Design Optimization of Silica Fume-Based Pervious Concrete for Removal of Heavy Metals from Wastewaters. Silicon 2018, 10, 1737-1744. [CrossRef]

116. Salem, A.; Sene, R.A. Removal of lead from solution by combination of natural zeolite-kaolin-bentonite as a new low-cost adsorbent. Chem. Eng. J. 2011, 174, 619-628. [CrossRef]

117. Kragović, M.; Daković, A.; Marković, M.; Petković, A.; Milojković, J.; Zildžović, S. Removal of lead and cadmium ions from aqueous solutions by using natural and modified zeolite. Adv. Sci. Lett. 2017, 23, 5862-5865. [CrossRef]

118. Moussavi, G.; Talebi, S.; Farrokhi, M.; Sabouti, R.M. The investigation of mechanism, kinetic and isotherm of ammonia and humic acid co-adsorption onto natural zeolite. Chem. Eng. J. 2011, 171, 1159-1169. [CrossRef]

119. Zhou, L.; Boyd, C.E. Total ammonia nitrogen removal from aqueous solutions by the natural zeolite, mordenite: A laboratory test and experimental study. Aquaculture 2014, 432, 252-257. [CrossRef]

120. Eva, C. Ammonia removal from water with natural zeolite clinoptilolite using the coagulation/flocculation vs. filtration techniques. Res. J. Chem. Environ. 2015, 19, 8-13.

121. Mažeikien, A.; Valentukevičien, M.; Jankauskas, J. Laboratory study of ammonium ion removal by using zeolite (Clinoptilolite) to treat drinking water. J. Environ. Eng. Landsc. Manag. 2010, 18, 54-61. [CrossRef]

122. Torma, S.; Vilček, J.; Adamišin, P.; Huttmanová, E.; Hronec, O. Influence of natural zeolite on nitrogen dynamics in soil. Turk. J. Agric. For. 2014, 38, 739-744. [CrossRef]

123. Ferretti, G.; Keiblinger, K.M.; Faccini, B.; Di Giuseppe, D.; Mentler, A.; Zechmeister-Boltenstern, S.; Coltorti, M. Effects of Different Chabazite Zeolite Amendments to Sorption of Nitrification Inhibitor 3,4-Dimethylpyrazole Phosphate (DMPP) in Soil. J. Soil Sci. Plant Nutr. 2020, 20, 973-978. [CrossRef]

124. Ferretti, G.; Keiblinger, K.M.; Zimmermann, M.; Di Giuseppe, D.; Faccini, B.; Colombani, N.; Mentler, A.; Zechmeister-Boltenstern, S.; Coltorti, M.; Mastrocicco, M. High resolution short-term investigation of soil $\mathrm{CO}_{2}, \mathrm{~N}_{2} \mathrm{O}, \mathrm{NO}_{\mathrm{x}}$ and $\mathrm{NH}_{3}$ emissions after different chabazite zeolite amendments. Appl. Soil Ecol. 2017, 119, 138-144. [CrossRef]

125. Tian, J.; Guan, J.; Gao, H.; Wen, Y.; Ren, Z. The adsorption and mass-transfer process of cationic red X-GRL dye on natural zeolite. Water Sci. Technol. 2016, 73, 2119-2131. [CrossRef]

126. Zolfaghari, M.; Magdouli, S.; Tanabene, R.; Komtchou, S.P.; Martial, R.; Saffar, T. Pragmatic strategy for the removal of ammonia from gold mine effluents using a combination of electro-coagulation and zeolite cation exchange processes: A staged approach. J. Water Process. Eng. 2020, 37, 101512. [CrossRef]

127. Khan, G.F.; Wood, J. Information technology management domain: Emerging themes and keyword analysis. Scientometrics 2015, 105, 959-972. [CrossRef]

128. Baier-Fuentes, H.; Merigó, J.M.; Amorós, J.E.; Gaviria-Marín, M. International entrepreneurship: A bibliometric overview. Int. Entrep. Manag. J. 2019, 15, 385-429. [CrossRef]

129. Dong, D.; Chen, M.-L. Publication trends and co-citation mapping of translation studies between 2000 and 2015. Scientometrics 2015, 105, 1111-1128. [CrossRef]

130. Jorgensen, T.; Weatherley, L. Ammonia removal from wastewater by ion exchange in the presence of organic contaminants. Water Res. 2003, 37, 1723-1728. [CrossRef]

131. Sheppard, R.A. Characterization of Zeolitic Materials in Agricultural Research; Westview Press: Boulder, CO, USA, 1984; pp. 81-90. 